tropin-releasing factor by arginine vasopressin. Peptides, 3: 111 (1982).

36. Wintour, E. M., Congiu, M., Hardy, K. J., and Hennessy, D. P.: Regulation of urine osmolality in fetal sheep. Q. J. Exp. Physiol., 67: 427 (1982).

37. Wiriyathian, S., Porter, J. C., Naden, R. P., and Rosenfeld, C. R.: Cardiovascular effects and clearance of exogenous arginine and vasopressin (AVP) in the fetal lamb. Am. J. Physiol., 245: E24 (1983).

38. Requests for reprints should be addressed to: Dr. R. I. Stark, Division of
Perinatal Medicine, Departments of Pediatrics, OB/GYN, and Anesthesiology, College of Physicians \& Surgeons, Columbia University, New York, NY 10032 .

39. This research was supported in part by grant HD-13063 from the National Institutes of Health.

40. Received for publication June 2, 1983.

41. Accepted for publication September 22, 1983.

\title{
Ontogeny of Insulin and Glucagon Receptors and the Adenylate Cyclase System in Guinea Pig Liver
}

\author{
SUPRIYA GANGULI ${ }^{(49)}$ MADHUR SINHA, AND MARK A. SPERLING with the technical assistance of \\ WALTER BANACH AND GLENDY HSIUNG
}

Division of Endocrinology, Children's Hospital Medical Center, Cincinnati, Ohio, USA

\section{Summary}

To gain insight into the mechanisms responsible for the impaired glycogenolytic response to glucagon and the diminished ketogenic capacity of newborn guinea pig, we studied the ontogeny of insulin and glucagon receptors, and the responsiveness of the adenylate cyclase complex to glucagon, $\mathrm{PGE}_{1}, \mathrm{NaF}$, and cholera toxin in liver plasma membrane from fetal $(58 \mathrm{~d}$, late gestation, and $65 \mathrm{~d}$, term) and adult guinea pigs. The number of insulin receptors $\left(\times 10^{-10} \mathrm{M} / \mathrm{L}\right)$ was least in 58-d fetus $(3.0 \pm$ 0.4 ; mean $\pm S E M)$ and increased 3 -fold in $65 \mathrm{~d}$ fetus $(8.8 \pm 0.6$; $P<0.01)$. In adult guinea pig, both insulin receptor number $(6.0$ $\pm 0.7)$ and average affinity constant $\left(1.20 \pm 0.08 \times 10^{8} \mathrm{M}^{-1}\right)$ were significantly lower $(P<0.01)$ compared with $65-d$ fetus. The number of glucagon receptors remained unchanged between 58-d and 65-d fetuses, but both average and high affinity association constants were significantly higher at $d 65$. In contrast to the lower capacity and affinity of insulin receptors in the adult compared with term fetus, the total glucagon receptor number $\left(\times 10^{-10} \mathrm{M} / \mathrm{L}\right)$ in adults $(7.2 \pm 0.8)$ was twice that of the $58 \mathrm{~d}$ $(3.2 \pm 0.2)$ and $65 \mathrm{~d}(3.2 \pm 1.0)$ fetuses. The average affinity constant $\left(\times 10^{8} \mathrm{M}^{-1}\right)$ in adult $(3.8 \pm 0.2)$ was, however, significantly lower than the two fetal groups $(58 \mathrm{~d}, 5.0 \pm 0.3 ; P<0.05$ and $65 \mathrm{~d}, 8.1 \pm 1.0 ; P<0.05)$. Although the total glucagon receptor number at d 58 was approximately $50 \%$ of that present in the adult, glucagon did not stimulate cAMP production above basal; all other stimuli evoked significant increases. By $65 \mathrm{~d}$, the fetal membranes responded to glucagon as well as to all other agents with appropriate cAMP production. In the presence of $0.5 \mathrm{mM}$ guanosine-5' - triphosphate, the cAMP response to prostaglandin $\mathrm{E}_{1}$ was similar in all three groups. These results demonstrate the following in liver plasma membrane from the guinea pig. 1) At term, insulin receptor numbers are higher than in less mature fetus or in adult. 2) There is a delay in maturation of functional glucagon receptors coupled to the adenylate cyclase complex. 3) Apart from failure of response to glucagon, the adenylate cyclase complex is otherwise functionally mature even at $58 \mathrm{~d}$ because it responds to $\mathrm{PGE}_{1}$ and other agents.
Abbreviations

BSA, bovine serum albumin

G/F, GTP binding protein

LPM, liver plasma membrane

M/L, moles per liter

$\mathrm{PGE}_{1}$, prostaglandin $\mathrm{E}_{1}$

A number of peptide hormones including insulin and glucagon are present in fetal mammals at an early gestational age $(3,15$, $29,39,41)$. The functional significance of these hormones during maturation of the developing fetus is, however, not adequately understood. There have been several reports regarding the ontogeny and development of insulin receptors in tissues such as liver, lung, heart, or circulating cells such as erythrocytes and monocytes $(3,14,17,21,22,33)$; glucagon receptor development in liver and heart has also been reported $(4,5,26,27,42,46)$. There seems to be general agreement that at term and in the immediate newborn period, insulin receptor number and/or affinity are greater than in corresponding adult tissues $(14,21$, 22,41 ). Conversely, glucagon receptor number seems to be lower in fetus and in newborn and increases gradually to reach adult levels during the first few weeks of life $(4,5,26,27,42,46)$.

In spite of the general agreement regarding the ontogenic pattern of insulin and glucagon receptors in various studies, there is inconsistency regarding the maturation of the post-receptor axis for these hormones $(4,7,12,26,27,42,46)$. For glucagon, this post-receptor complex involves the adenylate cyclase complex. The maturation of the adenylate cyclase complex and its expression as a stimulatable, functional unit and its ability to be coupled to the surface receptors seems to vary with type of tissue, surface receptor, and species $(6,7,11,18,24,25,43,44,46)$. During fetal and neonatal development of lung, the adenylate cyclase complex develops in parallel with the catecholamine receptors in most species examined $(44,45)$; however, maturation of brain adenylate cyclase activity lags behind the appearance of the catecholamine receptors $(11,18)$. Appropriate cou- 
pling between the receptor and the adenylate cyclase complex in this tissue occurs later than in heart and lung $(6,7,18,44-46)$. In liver, the development of the adenylate cyclase complex and its coupling to glucagon receptors is not well delineated. In fetal rat liver the adenylate cyclase complex is well developed, but glucagon receptor maturation lags $(2,26,42)$. In newborn guinea pig, the glycogenolytic response to glucagon does not develop its full responsivity until several hours after birth even though the post-receptor axis is well developed and intact because the glycogenolytic response to dibutyryl cAMP is normal (16). Similarly, the capacity for hepatic ketogenesis, a process activated by glucagon (20), is low in newborn guinea pig and increases sharply after $24 \mathrm{~h}$ of life (36).

The present study was undertaken to characterize the development of insulin and glucagon receptors, and the adenylate cyclase complex in the liver plasma membrane from the guinea pig fetus in late gestation and at term, when rapid and qualitative changes occur in the functional development and hormone sensitivity of the liver in this species $(16,36,37)$. The results in the fetus were compared with those from non-pregnant adult.

\section{MATERIALS AND METHODS}

Six adult guinea pigs (3-mo-old virgin females) and fetuses from two sets of pregnancies (six pregnancies each) late in gestation $(56-58 \mathrm{~d})$ and at term $(65 \mathrm{~d})$ were used in the studies. Food was withdrawn the evening before sacrifice. Between 0900$1000 \mathrm{~h}$ the animals were stunned and sacrificed by decapitation. The liver of non-pregnant adult females was removed quickly and placed in chilled bicarbonate buffer $(1 \mathrm{mM})$. The fetuses of pregnant females were delivered quickly, weighed, decapitated, and the livers rapidly excised. Livers from the fetuses of the same mother were pooled to provide sufficient yield; livers from the adults were individually processed.

Livers were minced in fresh chilled bicarbonate buffer and washed three times to remove blood and debris. The tissues were then processed as described by Neville et al. (23) up to step 11. The plasma membranes thus harvested were uniformly resuspended in a loose pestle hand homogenizer and diluted with bicarbonate buffer to yield a protein concentration of 3-5 $\mathrm{mg} /$ $\mathrm{ml}$. Membranes were aliquoted in small portions, snap frozen with dry ice in acetone, and stored at $-70^{\circ} \mathrm{C}$ for subsequent analysis. Protein concentrations were determined by the method of Lowry et al. (19) using BSA as the protein standard. To demonstrate the extent of purification and the comparability of adult and fetal guinea pig liver membranes in these studies, we determined membrane markers such as insulin and glucagon binding and degradation, $5^{\prime}$ nucleotidase activity, and glucose6-phosphatase activity in the crude homogenate and in the partially purified LPM.

Glucagon and insulin binding assay. Insulin and glucagon binding to partially purified LPM and crude liver homogenate was measured using the following materials: monoiodinated insulin (approximately $100 \mu \mathrm{Ci} / \mu \mathrm{g}$ ), prepared by a minor modification of the method of Sodoyez et al. (34); highly purified crystalline insulin (gift of Dr. Chance of Eli Lilly and Company); monoiodinated glucagon (approximately $250 \mu \mathrm{Ci} / \mu \mathrm{g}$ ), prepared according to the method of Jorgensen and Larsen (13); and highly purified glucagon, a gift of Dr. Mary Root (Eli Lilly and Company).

The binding and degradation assays were carried out in microfuge tubes (polyethylene) in the following manner. Fifty micrograms of LPM protein for glucagon, $100 \mu \mathrm{g}$ membrane protein for insulin, and $100 \mu \mathrm{g}$ protein of crude homogenate were used in a total volume of $300 \mu \mathrm{l}$ of $50 \mathrm{mM}$ tris buffer, $\mathrm{pH} 7.6$ containing $1 \% \mathrm{BSA}, 2 \mathrm{mg} / \mathrm{ml}$ bacitracin, $500 \mathrm{U} / \mathrm{ml}$ Trasylol, and various concentrations $\left(0-10^{-7} \mathrm{M}\right)$ of native glucagon or insulin. The tubes were incubated for $16 \mathrm{~h}$ at $4^{\circ} \mathrm{C}$. Approximately 20,000 count $/ \mathrm{min}$ of labeled insulin $(0.017 \mathrm{pmol})$ or labeled glucagon $(0.015 \mathrm{pmol})$ was added to each tube.
After incubation the tubes were spun for $5 \mathrm{~min}$ in a microfuge and the supernatant carefully removed by aspiration. Radioactivity in the membrane pellet was measured in a gamma counter. Nonspecific binding was defined as the residual counts remaining in the presence of an excess of native hormone $\left(1 \times 10^{-6} \mathrm{M}\right)$ and was subtracted from all subsequent calculations. These incubation conditions were followed because in our laboratory, under these conditions, the insulin and glucagon degradation was minimal without any significant reduction of binding (35). There was no significant difference between the adult and fetal LPM in terms of insulin and glucagon degradation as determined by trichloroacetic acid precipitation. The nonspecific binding did not exceed $3 \%$ of the total for insulin and $5 \%$ of the total for glucagon. All binding studies were performed in triplicate, and each point in the displacement curve for individual animals or for the fetal pool represents the mean value of these three replicates. The dose-response curve of binding was analyzed by Scatchard plots (35) and the curvilinear plots thus obtained were resolved further into two linear components by the method of Rosenthal, using a computer program $(31,40)$.

Insillin degradation. Insulin degradation in crude liver homogenate and in the paritally purified liver plasma membrane was determined by the same protocol used above for insulin binding, except that the bacitracin and Trasylol were omitted from the incubation medium. After centrifugation the supernatant was evaluated for insulin degradation by trichloroacetic acid precipitation. Percentage degradation was calculated as

$$
\frac{\mathrm{CPM} \text { in membrane supernatant }(\mathrm{PPT})}{\mathrm{CPM} \text { in supernatant without membrane }(\mathrm{PPT})} \times 100
$$

\section{ADENYLATE CYCLASE ACTIVITY}

Adenylate cyclase activity was determined according to the method of Pohl et al. with minor modification (28, 35). Fifty micrograms of LPM was incubated for $10 \mathrm{~min}$ at $30^{\circ} \mathrm{C}$ in a shaking water bath in the presence of $0.8 \mathrm{mM}$ ATP and an ATP regenerating system in $50 \mathrm{mM}$ Tris- $\mathrm{HCl}$ buffer, $\mathrm{pH}$ 7.6. To assess the sensitivity of the receptor-adenylate cyclase complex various concentrations of glucagon $\left(10^{-6}\right.$ to $\left.10^{-9} \mathrm{M}\right)$ and $\mathrm{PGE}_{1}\left(10^{-4}\right.$ to $10^{-7} \mathrm{M}$ ) were used. PGE was a gift of Dr. John Pike, of the Upjohn Company, Kalamazoo, MI. The dose response curves for glucagon and $\mathrm{PGE}_{1}$ were performed in the presence as well as in the absence of $0.5 \mathrm{mM}$ GTP in the cAMP generating medium. In a separate series of experiments we assessed the effect of $0.5 \mathrm{mM} \mathrm{Gpp} \mathrm{(NH)}$, a non-hydrolyzable analog of GTP, on basal as well as on glucagon-stimulated cAMP production. In these experiments, GTP was replaced by $0.5 \mathrm{mM}$ Gpp (NH)p in the cAMP generating medium. After incubation, the reaction was terminated by diluting the reaction mixture with $1 \mathrm{ml}$ of chilled $50 \mathrm{mM}$ sodium acetate buffer, $\mathrm{pH}$ 6.2. The tubes were immediately placed in a boiling water bath for $3 \mathrm{~min}$. After centrifugation at $2200 \mathrm{~g}$ for $20 \mathrm{~min}$, the supernatant was separated and kept frozen at $-20^{\circ} \mathrm{C}$ for cAMP determination. cAMP concentration was measured by a specific radioimmunoassay according to the method of Steiner et al., using an antibody kindly donated by Dr. Alton Steiner (38). This system has an absolute sensitivity of $0.1 \mathrm{pM}$ per tube, thereby permitting detection of $1 \mathrm{pM} / \mathrm{ml}$; the intraassay coefficient of variation is $7 \%$ and interassay variation is less than $12 \%$.

Time course of activation of adenylate cyclase. Fifty micrograms of LPM from 56-58-d fetus and from adult was incubated in the presence of a maximal dose of glucagon $\left(10^{-6} \mathrm{M}\right)$ in the cAMP generation using the same conditions as described above. Duplicate aliquots were removed at timed intervals and CAMP measured by radioimmunoassay as described.

\section{CHOLERA TOXIN-STIMULATED CAMP PRODUCTION}

Activation of cholera toxin. One hundred micrograms of cholera toxin was incubated in a final volume of $200 \mu \mathrm{l}$ of $100 \mathrm{mM}$ 
Tris- $\mathrm{HCl}$ buffer $\mathrm{pH} 7.6$ containing $40 \mathrm{mM}$ dithiothreitol for 30 $\min$ at $37^{\circ} \mathrm{C}$.

Ribosylation of liver plasma membrane by activated cholera toxin. One and one-half milligrams of LPM protein was suspended in $0.5 \mathrm{ml}$ of $50 \mathrm{mM}$ Tris- $\mathrm{HCl}$ buffer containing $1 \mathrm{mM}$ dithiothreitol, $1 \mathrm{mM}$ NAD, $1 \mathrm{mM}$ ATP and $10 \mu \mathrm{g}$ of activated cholera toxin. The mixture was incubated for $20 \mathrm{~min}$ at $30^{\circ} \mathrm{C}$ in a shaking water bath and the reaction terminated by the addition of $12 \mathrm{ml}$ of ice cold $50 \mathrm{mM}$ Tris- $\mathrm{HCl}$ buffer, $\mathrm{pH} \mathrm{7.6}$. The tubes were then centrifuged at $20,000 \mathrm{~g}$ for $15 \mathrm{~min}$ at $4^{\circ} \mathrm{C}$. Ribosylated membranes were resuspended and homogenized in $50 \mathrm{mM}$ Tris $\mathrm{HCl}$ buffer, $\mathrm{pH}$ 7.6. The method is essentially the same as described by Entomoto et al., with minor modifications (10). Protein was determined by the Lowry method (19) and cAMP generation by these membranes was assayed as described above.

\section{MEMBRANE MARKERS}

5' Nucleotidase. 5' Nucleotidase activity was determined by the method of Dixon and Purdon (9). One hundred micrograms of protein was incubated for $15 \mathrm{~min}$ at $30^{\circ} \mathrm{C}$ in a shaking bath. The reaction was terminated by adding $10 \%$ trichloroacetic acid, the tubes centrifuged at $1500 \mathrm{~g}$ for $15 \mathrm{~min}$, and phosphate content in the supernatant was measured as follows: $1 \mathrm{ml}$ of the supernatant was thoroughly mixed with $1 \mathrm{ml}$ of $1 \%$ ammonium molybdate. After $30 \mathrm{~s}, 1 \mathrm{ml}$ of $2 \%$ arsenite-citrate was added. The assay tubes were allowed to stand for $15 \mathrm{~min}$ and absorbance measured by a spectrophotometer at a wave length of $700 \mathrm{~nm}$.

Glucose-6-phosphatase. Glucose-6-phosphatase activity was determined by the method of Baginski et al. (1) using $25 \mathrm{mM}$ cacodylate buffer with $62.5 \mathrm{mM}$ sucrose, $0.25 \mathrm{mM}$ EDTA, 25 $\mathrm{mM}$ glucose-6-phosphate, and $100 \mu \mathrm{g}$ of membrane protein. The duplicate assay tubes were incubated for $30 \mathrm{~min}$ at $37^{\circ} \mathrm{C}$ with shaking, the reaction terminated with $10 \%$ trichloroacetic acid followed by centrifugation at $1500 \mathrm{~g}$ for $15 \mathrm{~min}$. The supernatant was used for colorimetric determination of free phosphate. The reagent blank differed in that the protein was added after the trichloroacetic acid. A water blank and phosphate standards were run along with the samples.

Statistical analysis. Unpaired Students $t$ test was performed to determine the level of significance. $P<0.05$ was accepted as significant between two groups.

\section{RESULTS}

Table 1 demonstrates the degree of purification of the membrane markers. The degree of purification of the LPM for the three groups is the same when judged from the specific activity of the membrane marker enzymes and from increased insulin binding in the purified membranes when compared with the crude homogenate. In general, there was a 5-8-fold increase in $5^{\prime}$ nucleotidase and specific binding of insulin in the partially purified membranes relative to crude homogenate in fetal as well as adult tissue. Glucose-6-phosphatase, a cytosolic enzyme, decreased with purification in adult LPM as previously reported, but did not appreciably change in either of the fetal groups.

Insulin binding characteristics for fetal and adult LPM are presented in Table 2 and Figure 1. The percentage specific binding (Bo) and the total insulin bound $\left(\times 10^{-10} \mathrm{M} / \mathrm{L}\right)$ were significantly higher in the $65-\mathrm{d}$ fetus than in the adult or the 5658-d fetus. Scatchard plots of the binding data for all three groups were curvilinear and therefore compatible with either the negative cooperativity model of deMeyts et al. (8) or at least 2 orders of binding sites. When the curves were resolved into their two linear components, the affinity constant $(\mathrm{Ka})$ for the high affinity sites was significantly higher in the 65-d fetus than in the adult or the 56-58-d fetus. The total number of receptors per mg membrane protein (Ro) and the number of low-affinity receptor sites $\left(R_{2}\right)$ were also significantly higher in the 65-d fetus than in the other two groups. The receptor number at the high affinity sites was significantly lower in the 56-58-d group than in the adult and the 65-d fetus; thus, with the exception of the number of high affinity receptor sites, the 56-58-d fetus was comparable to the adult whereas the $65-\mathrm{d}$ fetus was higher than either the adult or the 56-58-d fetus in all parameters examined.

Data for glucagon binding are presented in Figure 2 and Table 3. Scatchard analysis of the glucagon binding data also resulted in curvilinear plots for both adult and fetal groups compatible with either negative cooperativity or a two-site model. The percentage specific binding of glucagon was not different in the 65 -d fetus and adult groups, but was significantly lower in the $56-58-d$ fetus. The total number of receptor sites $\left(\times 10^{-10} \mathrm{M} / \mathrm{L}\right)$ was similar in the two fetal groups and was approximately half of that of the adult. The increase in percentage binding, therefore, in the 65-d fetus could be attributed to a much higher affinity constant for the high affinity sites which was significantly lower in the adult than in both fetal groups; the same was true for the mean affinity $(\overline{\mathrm{Ke}})$. In the presence of GTP $1 \times 10^{-4} \mathrm{M},\left[{ }^{125} \mathrm{I}\right]$ glucagon binding was reduced in all three groups. The percentage reduction was not significant in the 56-58-d group $(7.6 \pm 4.5, n$ $=6)$ but was highly significant in both the 65-d group $(25.1 \pm$ $6.2 ; n=5, P<0.01)$ as well as the adult group (45.4 $\pm 4.1 ; n=$ $5, P<0.001)$.

Figure 3 represents the time course for the activation of adenylate cyclase in the adult and 58-d fetal LPM. Because values at $30 \mathrm{~min}$ were not significantly different from values at $10 \mathrm{~min}$, in all subsequent studies the membranes were incubated for $10 \mathrm{~min}$.

The cAMP response to glucagon and PGE, is shown in Figures 4 and 5 , respectively. Both in the absence and presence of $5 \times$ $10^{-4} \mathrm{M}$ GTP, adult guinea pigs responded in a dose-dependent manner to glucagon stimulation and reached their maximum

Table 1. Characteristics of guinea pig liver plasma membranes*

\begin{tabular}{|c|c|c|c|c|c|c|}
\hline \multirow[b]{2}{*}{ Marker } & \multicolumn{2}{|c|}{ Adult $(n)$} & \multicolumn{2}{|c|}{$56-58-\mathrm{d}$ fetus $(n=4)$} & \multicolumn{2}{|c|}{$65-\mathrm{d}$ fetus $(n=4)$} \\
\hline & $\begin{array}{c}\text { Crude } \\
\text { homogenate }\end{array}$ & $\begin{array}{l}\text { Partially } \\
\text { purified }\end{array}$ & $\begin{array}{c}\text { Crude } \\
\text { homogenate }\end{array}$ & $\begin{array}{l}\text { Partially } \\
\text { purified }\end{array}$ & $\begin{array}{c}\text { Crude } \\
\text { homogenate }\end{array}$ & $\begin{array}{l}\text { Partially } \\
\text { purified }\end{array}$ \\
\hline $\begin{array}{l}5^{\prime} \text { Nucleotidase }\left(\mu \mathrm{mol} \mathrm{PO}_{4} \cdot \mathrm{mg} \text { pro- }\right. \\
\left.\text { tein }^{-1} \cdot \mathrm{h}^{-1}\right)\end{array}$ & $0.37 \pm 0.09$ & $2.6 \pm 0.56 \dagger$ & $0.42 \pm 0.08$ & $2.7 \pm 0.54 \dagger$ & $0.34 \pm 0.07$ & $2.5 \pm 0.10 \dagger$ \\
\hline $\begin{array}{l}\text { Specific binding of }\left[{ }^{125} I\right] \text { insulin (per } \\
100 \mu \mathrm{g} \text { membrane protein) }\end{array}$ & $5.6 \pm 1.0$ & $42.0 \pm 4.0 \dagger$ & $3.6 \pm 0.80$ & $30.0 \pm 6.4 \dagger$ & $7.8 \pm 0.68 \dagger$ & $63.7 \pm 1.2 \dagger \ddagger$ \\
\hline $\begin{array}{l}\text { Insulin degradation (\% intact insu- } \\
\text { lin after binding) }\end{array}$ & $87.0 \pm 6.0$ & $>95$ & $86.0 \pm 8.0$ & $>95$ & $84.0 \pm 7.0$ & $>95$ \\
\hline $\begin{array}{l}\text { Glucose-6-Phosphatase }\left(\mu \mathrm{mol} \mathrm{PO}_{4} \text {. }\right. \\
\left.\text { mg protein }{ }^{-1} \cdot \mathrm{h}^{-1}\right)\end{array}$ & $15.1 \pm 2.5$ & $4.4 \pm 0.57 \dagger$ & $1.1 \pm 0.11$ & $1.8 \pm 0.64$ & $1.2 \pm 0.17$ & $2.1 \pm 0.59$ \\
\hline
\end{tabular}

$*$ Values are mean \pm SEM.

$\dagger P<0.05$ compared with crude homogenate.

$\ddagger P<0.05$ compared with 58 -d fetus. 


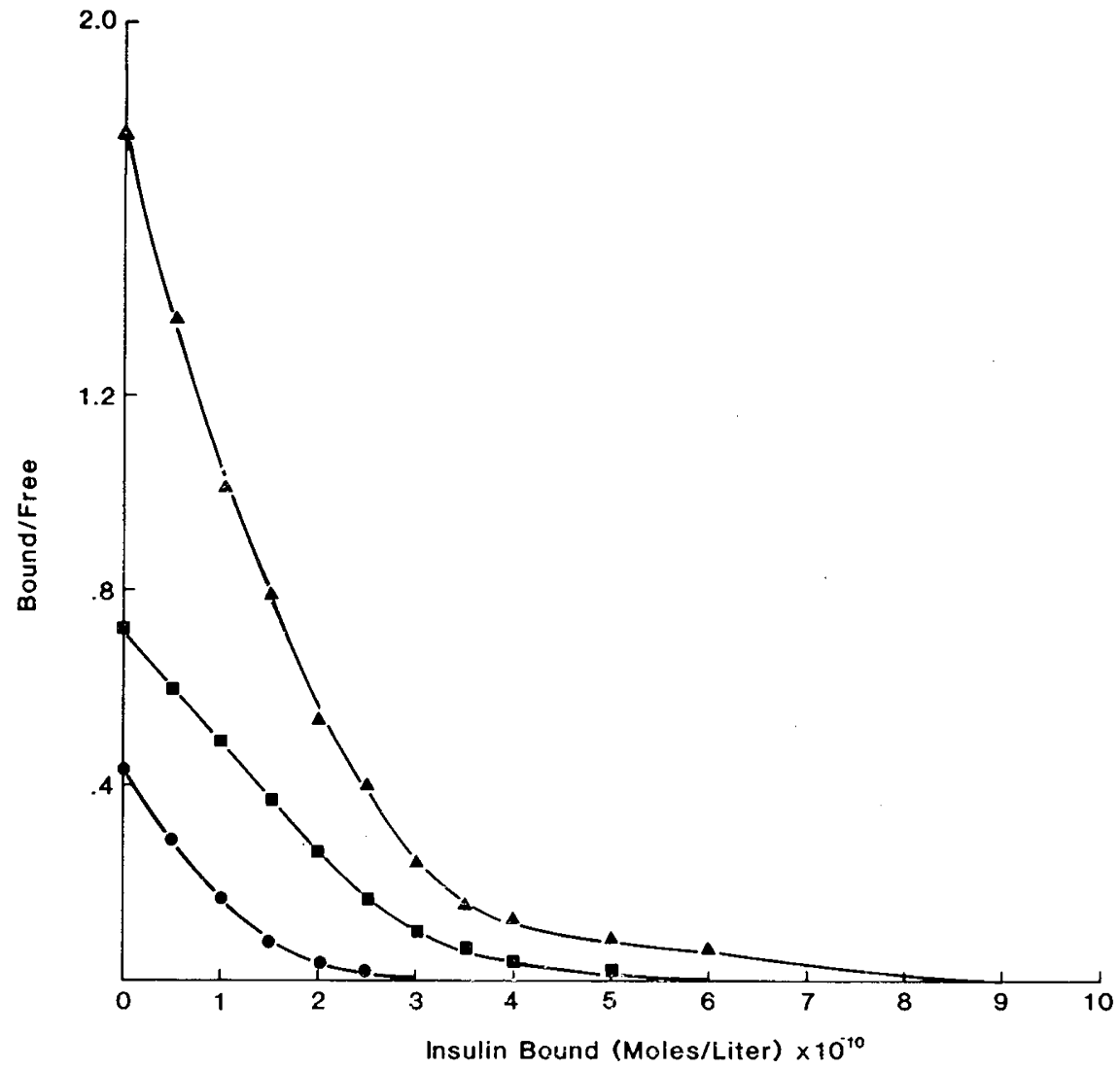

Fig. 1. The Scatchard plots of the insulin binding data. Liver piasma membrane (LPM) (100 $\mu \mathrm{g}$ protein) from 56-58-d fetus (@- $\longrightarrow$ ), 65-d fetus ( $60 \mathrm{pg})$ and various concentrations of porcine insulin $\left(0-10^{-7} \mathrm{M}\right)$. At the end of incubation the supernatant was removed after centrifugation and the membranc-bound $\left[{ }^{125} \mathrm{l}\right]$ insulin radioactivity was assessed. Radioactivity in the presence of $10^{-7} \mathrm{M}$ insulin (nonspecific binding) was subtracted from all points. Binding data were plotted as bound/free $v s$ insulin bound $(\mathrm{M} / \mathrm{L})$. Each point represents mean of six experiments performed with different LPM pools. Binding for each pool was run in triplicate.

Table 2. Insulin receptor characteristics of the guinea pig liver plasma membrane (100 $\mathrm{g}$ membrane protein)*

\begin{tabular}{|c|c|c|c|c|c|c|c|}
\hline & \multirow{2}{*}{$\begin{array}{c}\text { Percentage } \\
\text { bound }\end{array}$} & \multicolumn{3}{|c|}{ Affinity Constant $\times 10^{9} \mathrm{M}^{-1}$} & \multicolumn{3}{|c|}{ Receptor number $\left(\mathrm{M} / \mathrm{L} \times 10^{-10}\right)$} \\
\hline & & $\mathrm{Ka}_{1}$ & $\mathrm{Ka}_{2}$ & $\overline{\mathrm{K}} \mathrm{e}$ & $\mathrm{R}_{1}$ & $\mathrm{R}_{2}$ & $\mathrm{R}_{0}$ \\
\hline $\begin{array}{c}65-\mathrm{d} \text { fetus } \\
\quad(n=6)\end{array}$ & $68 \pm 6.2 \dagger$ & $7.53 \pm 0.1^{*}$ & $0.2 \pm 0.04$ & $1.99 \pm 0.19 \dagger$ & $2.15 \pm 0.02$ & $6.64 \pm 0.8 \dagger$ & $8.8 \pm 0.6 \dagger$ \\
\hline $\begin{array}{l}\text { Adult } \\
\qquad(n=6)\end{array}$ & $42 \pm 3.3$ & $2.3 \pm 0.4$ & $0.14 \pm 0.01$ & $1.20 \pm 0.08$ & $2.92 \pm 0.4$ & $3.08 \pm 0.2$ & $6.0 \pm 0.7$ \\
\hline
\end{tabular}

* Values are mean $\pm \mathrm{SEM}$. Bo is total binding, $\mathrm{Ka}_{1}$, high affinity constant; $\mathrm{Ka}_{2}$, low affinity constant; $\overline{\mathrm{K}} \mathrm{e}$, mean affinity; Ro, total receptor; $\mathrm{R}_{1}$, high affinity receptor; and $\mathrm{R}_{2}$, low affinity receptor.

$\dagger P<0.05$ compared with 56-58-d fetus and adult.

$\ddagger P<0.05$ compared with 65 -d fetus and adult.

cAMP levels at glucagon concentrations of $10^{-7} \mathrm{M}$ (Fig. 4). The 65-d fetus also reached its maximurn cAMP at the same glucagon dose. In this group. the response above basal was significant; however, the maximum response was significantly below (40\%) the adult maximum. In contrast to these two groups, glucagon failed to evoke a significant cAMP response in the 56-58-d fetus either in the absence or in the presence of GTP. With GTP, however, basal cAMP production increased by $2-3$-fold above basal levels without GTP. GTP by itself was capable, therefore, of promoting increased levels of cAMP in the 56-58-d fetus even though the membrane failed to respond to glucagon at a dose that saturated all available glucagon receptors (Fig. 4).
All membranes responded to $\mathrm{PGE}_{1}$ in a dose-dependent manner (Fig. 5). In the absence of GTP (upper panel), cAMP production was highest in the adult, and lowest in the 56-58-d fetus. In the presence of $5.0 \times 10^{-4} \mathrm{M} \mathrm{GTP}$, both the basal and the $P_{\text {GE }}$ stimulated values increased significantly in all groups and the cAMP responses were indistinguishable among the groups (Fig. 5 lower panel). GTP restored the cAMP response to PGE in the fetus to that of adult.

Table 4 demonstrates the effect of various agents known to stimulate CAMP at distinct loci of the adenylate cyclase complex. Although LPM from the 56-58-d fetus exhibit a lower basal cAMP value (Fig. 4), PGE $1\left(10^{-4} \mathrm{M}\right), \mathrm{Gpp}(\mathrm{NH}) \mathrm{p}\left(5 \times 10^{-4} \mathrm{M}\right)$, 
cholera toxin $(5 \mu \mathrm{g} / \mathrm{ml})$, and $\mathrm{NaF}(15 \mathrm{mM})$ evoked a similar increment in cAMP, expressed as percentage change above basal, as that obtained by these agents in the other two groups; GTP or $\mathrm{Gpp}(\mathrm{NH}) \mathrm{p}$ was present in these assays. The only deficiency was in the cAMP response to glucagon. In the 65-d fetus, the cAMP response to glucagon improved significantly but was still markedly less than the response in adult. The basal cAMP levels appeared to follow a similar age-related increase (Figs. 4 and 5).

\section{DISCUSSION}

Using the guinea pig model we demonstrate that the number as well as the affinity of insulin and glucagon receptors in liver plasma membranes change with maturation. For insulin, specific binding and receptor number of both classes of receptor sites was lowest in the 56-58-d fetus and highest in the 65-d fetus, i.e., at term. In the adult the total insulin receptor number was lower than at term, but higher than in the 56-58-d fetus; thus, there are rapid changes in the insulin receptor during the final week of gestation in the guinea pig, followed by further changes proceeding to adult. This finding agrees with several other pub-

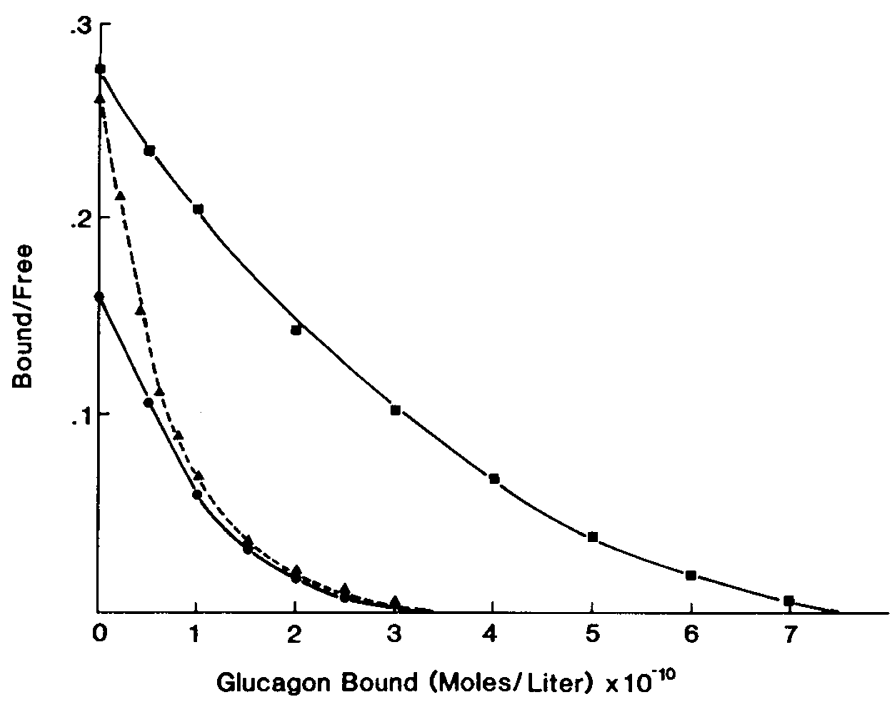

Fig. 2. Glucagon binding to liver plasma membrane (LPM) from 5658-d fetus $(-\longrightarrow)$, 65-d fetus $(\boldsymbol{\Lambda} \longrightarrow \mathbf{\Delta})$, and adult $(\mathbf{\square}-\mathbf{\square})$. Fifty micrograms of protein was incubated in $300 \mu \mathrm{l}$ of $50 \mathrm{mM}$ Tris buffer $\mathrm{pH} 7.6$ containing $1 \%$ bovine serum albumin, $\left[{ }^{125} \mathrm{I}\right] \mathrm{glucagon}(50-$ $60 \mathrm{pg})$ and various concentrations of unlabeled glucagon $\left(0-10^{-6} \mathrm{M}\right)$ for $16 \mathrm{~h}$ at $4^{\circ} \mathrm{C}$. Supernatant was removed after centrifugation and $\left[{ }^{125} \mathrm{I}\right]$ glucagon binding to the membrane pellet was assessed. The radioactivity in the presence of $1 \times 10^{-6} \mathrm{M}$ glucagon (nonspecific binding) was subtracted from all points. The binding data were plotted as bound/free $v$ s. glucagon bound $(\mathrm{M} / \mathrm{L}$ ) according to Scatchard. Each point represents mean of six experiments performed with different LPM pools. Binding for each pool was run in triplicate. lished reports of higher insulin receptor number and/or affinity, on circulating cell as well as in other fetal tissues such as liver and lung close to term $(3,14,17,21,22,33)$.

Ontogeny of the hepatic glucagon receptor differs markedly from that of the insulin receptor. Glucagon binding as well as receptor number per $\mathrm{mg}$ protein were low in the 56-58-d fetus, similar to the situation for the insulin receptor. By $65 \mathrm{~d}$ there was a significant increase in glucagon binding, due to a sharp rise in the affinity constant of the high affinity receptor sites $\left(K \mathrm{a}_{1}\right)$; total receptor number had not changed nor had the number of high or low affinity sites (Table 3). In contrast to insulin, glucagon receptor number continued to increase postnatally so that receptor concentration was significantly higher in the adult than in either fetal group. But the average receptor affinity $(\overline{\mathrm{K}})$ as well as the affinity constant for the high affinity sites were lower in the adult group than in either fetal group. It appears that there are quantitative and qualitative differences between the adult and the fetal groups in glucagon receptor characteristics.

The cAMP response to glucagon also differs significantly among these three groups. Although the number of glucagon receptors per $\mathrm{mg}$ protein in the 56-58-d group was the same as in the term fetus ( $65 \mathrm{~d}$ ), and about half that present in the adult, no significant increase in cAMP production occurred in response to glucagon; the response in the 65-d group was intermediate to that of adult. Furthermore, the defect in cAMP production by glucagon was not improved in the presence of GTP.

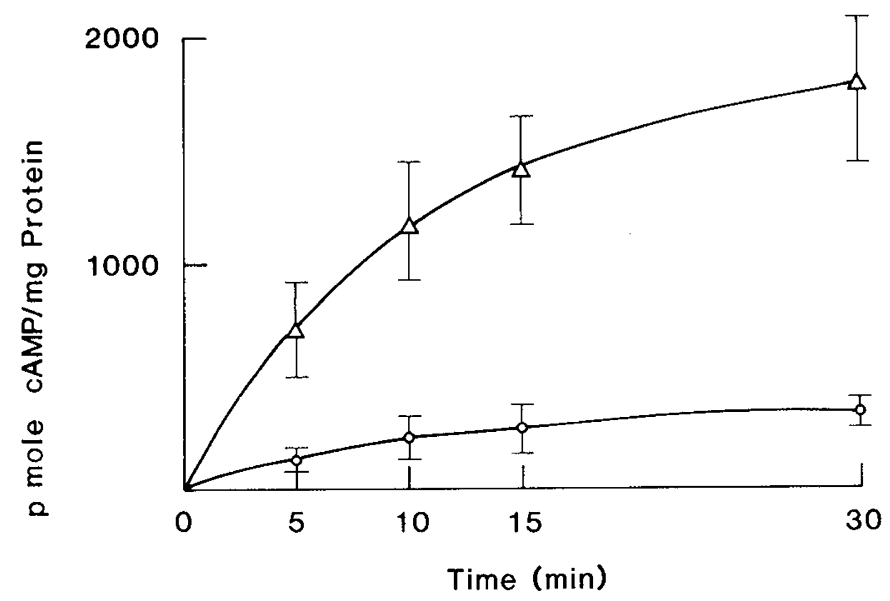

Fig. 3. Time course for activation of adenylate cyclase. Liver plasma membrane (LPM) $(50 \mu \mathrm{g}$ protein) from $56-58-\mathrm{d}$ fetus $(\mathrm{O}-\mathrm{O})$ and adult $(\triangle \longrightarrow \triangle)$ was incubated at $30^{\circ} \mathrm{C}$ in the presence of $0.8 \mathrm{mM}$ ATP, an ATP regenerating system, and glucagon $\left(10^{-6} \mathrm{M}\right)$. Duplicate sets of tubes were removed at indicated periods and cAMP produced was measured by a specific radioimmunoassay. Each value represents mean \pm SEM for two independent experiments run in duplicate. For cAMP determination, each tube was run in triplicate.

Table 3. Glucagon receptor characteristics of the guinea pig liver plasma membrane (50 $\mu \mathrm{g}$ membrane protein)

\begin{tabular}{|c|c|c|c|c|c|c|c|}
\hline & \multirow{2}{*}{$\begin{array}{c}\text { Percent bound } \\
\text { Bo }\end{array}$} & \multicolumn{3}{|c|}{ Affinity Constant $\times 10^{8} \mathrm{M}^{-1}$} & \multicolumn{3}{|c|}{ Receptor number $\left(\mathrm{M} / \mathrm{L} \times 10^{-10}\right)$} \\
\hline & & $\mathrm{Ka}_{1}$ & $\mathrm{Ka}_{2}$ & $\overline{\mathrm{K}} \mathrm{e}$ & $\mathrm{R}_{1}$ & $\mathrm{R}_{2}$ & $\mathrm{R}_{0}$ \\
\hline $\begin{array}{l}\text { 56-58-d fetus } \\
(n=6)\end{array}$ & $13.8 \pm 1.4$ & $12.3 \pm 1.5$ & $0.64 \pm 0.11$ & $5.0 \pm 0.3$ & $1.19 \pm 0.3$ & $2.0 \pm 0.23$ & $3.2 \pm 0.2$ \\
\hline $\begin{array}{l}65-\mathrm{d} \text { fetus } \\
\quad(n=6)\end{array}$ & $20.6 \pm 2.8 \dagger$ & $37.6 \pm 2.7 \dagger$ & $1.54 \pm 0.2$ & $8.1 \pm 1.0 \dagger$ & $0.58 \pm 0.1$ & $2.6 \pm 0.32$ & $3.2 \pm 1.0$ \\
\hline $\begin{array}{l}\text { Adult } \\
\qquad(n=6)\end{array}$ & $21.0 \pm 1.9 \dagger$ & $6.3 \pm 0.8 \dagger \ddagger$ & $0.94 \pm 0.08$ & $3.8 \pm 0.2 \dagger \ddagger$ & $3.85 \pm 0.4 \dagger t$ & $3.4 \pm 0.27 \dagger$ & $7.2 \pm 0.8 \dagger+$ \\
\hline
\end{tabular}

* Values are mean \pm SEM. Bo is total binding; $\mathrm{Ka}_{1}$, high affinity constant; $\mathrm{Ka}_{2}$, low affinity constant; $\overline{\mathrm{K}}$, mean affinity; Ro, total receptor; $\mathrm{R}_{1}$, high affinity receptor; and $\mathrm{R}_{2}$, low affinity receptor.

$\dagger P<0.05$ compared with 56-58-d fetus.

$\$ P<0.05$ compared with 65 -d fetus. 


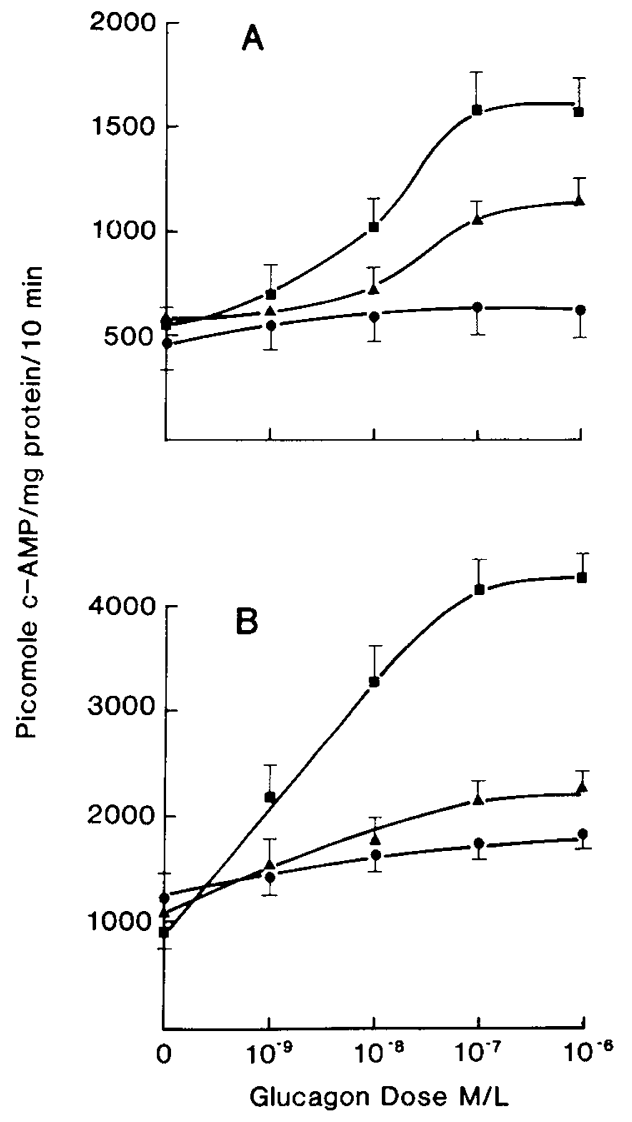

Fig. 4. Glucagon-stimulated cAMP production by the liver plasma membrane adenylate cyclase. Liver plasma membrane (LPM) $(50 \mu \mathrm{g}$ protein) from 56-58-d fetus $(\longrightarrow)$, 65-d fetus $(\boldsymbol{\Delta} \longrightarrow \mathbf{\Delta})$, and adult (_ـ ) was incubated at $30^{\circ} \mathrm{C}$ for $10 \mathrm{~min}$ in a total volume of $250 \mu \mathrm{l}$ of Tris- $\mathrm{HCl}$ buffer ( $\mathrm{pH} 7.6$ in the presence of $0.8 \mathrm{mM} \mathrm{ATP}$ ), an ATP regenerating system, and various concentrations of glucagon $(0-$ $10^{-6} \mathrm{M}$ ). cAMP was measured by a specific radioimmunoassay. Values represent mean \pm SEM from six separate pools of LPM. The upper panel represents cAMP production in the absence of any added GTP. The lower pand represents cAMP values in the presence of $0.5 \mathrm{mM}$ GTP in the generating medium.

To examine whether the absence of cAMP response to glucagon was due to a specific defect in the linkage between glucagon receptors and the adenylate cyclase complex, or to a defect in this complex distal to the receptor, we stimulated LPM of all three groups with agents such as Gpp (NH)p and cholera toxin, which directly activate adenylate cyclase through the regulatory protein (30), or with $\mathrm{NaF}$ that activates the adenylate cyclase non-specifically. cAMP increased sites is significantly lower in the adult whereas total receptor number and high affinity sites increase. From the binding data and the dose response curve, it can be shown that at a dose of glucagon at which $50 \%$ of high affinity sites are occupied, the cAMP response is not different from the 0 glucagon dose, both in adult and $65-\mathrm{d}$ fetus. But the glucagon dose necessary for a $50 \%$ response in cAMP corresponds closely with the dose necessary for $50 \%$ receptor occupancy of the low affinity receptor population. It may be proposed that the low affinity glucagon receptors are functional; a change towards lower affinity for the receptors may represent a more mature population of receptor coupled to adenylate cyclase. As indicated, however, neither changes in number nor affinity can completely explain the progressive maturation of cAMP response to glucagon.

The changes in the insulin and glucagon receptor characteristics and cAMP responsiveness could not be attributed to differences in the membrane preparations. Membranes from the adult and the two fetal groups demonstrate a similar degree of purifi-

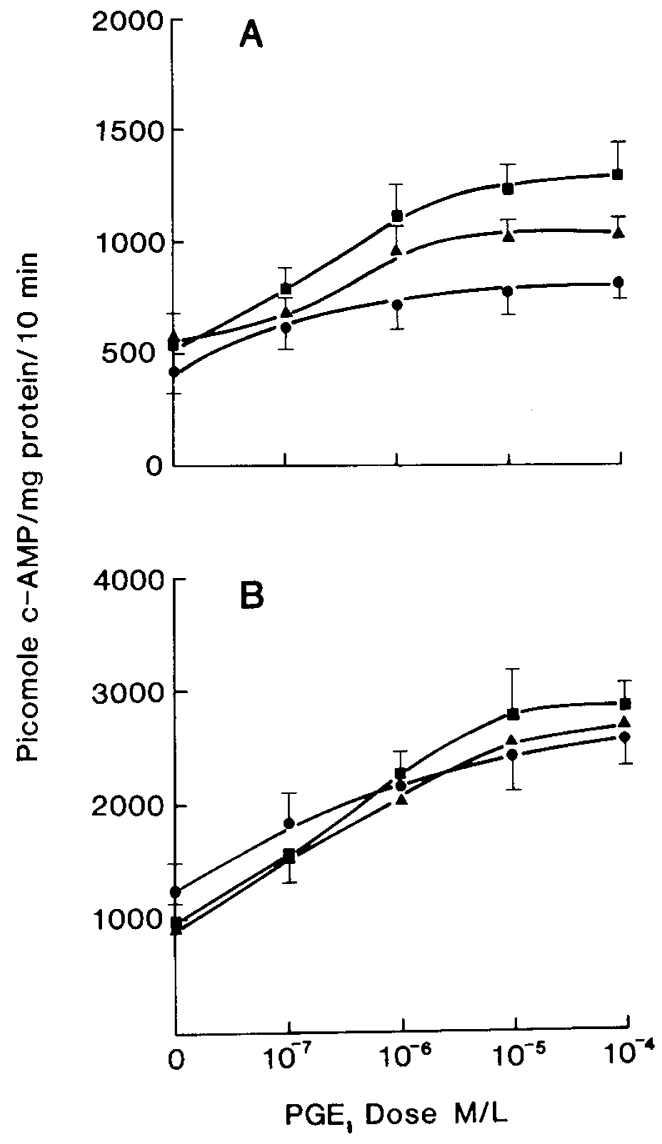

Fig. 5. Prostaglandin $E_{1}$-stimulated cAMP production by the liver plasma membrane adenylate cyclase. Liver plasma membrane (LPM)

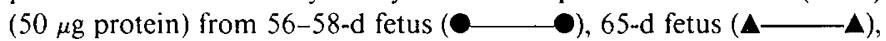
and adult (—) was incubated at $30^{\circ} \mathrm{C}$ for $10 \mathrm{~min}$ in a total volume of $250 \mu$ l of Tris buffer ( $\mathrm{pH} 7.6$ in the presence of $0.8 \mathrm{mM} \mathrm{ATP}$ ) an ATP regenerating system, and various concentrations of prostaglandin $E_{1}(0-$ $\left.10^{-4} \mathrm{M}\right)$. cAMP production was measured by a specific radioimmunoassay. Values represent mean \pm SEM from six separate pools of LPM. The upper panel shows the cAMP production in the absence of any added GTP. The lower panel represents cAMP production in the presence of $0.5 \mathrm{mM} \mathrm{GTP}$ in the generating medium.

cation in $5^{\prime}$-nucleotidase, insulin binding capacity, and insulin degradation. A significant disparity exists, however, in the levels of glucose-6-phosphatase. In adult membrane we found a 4-fold reduction in glucose-6-phosphatase concentration in the purified membrane as previously reported $(23,28)$. In fetal groups, the levels of glucose-6-phosphatase remain similar in both crude and purified membrane. This finding suggests a difference in the localization of glucose-6-phosphatase between adult and fetal liver because three other markers point to a comparable degree of purification in membranes from all ages studied. Furthermore, in spite of the identical purification of all markers used in the 65-d group and the 56-58-d group, glucagon binding as well as glucagon stimulated cAMP production was significantly different at $65 \mathrm{~d}$.

Receptor number also cannot completely explain the difference in cAMP response to glucagon because the 65-d fetus responds whereas the 56-58-d fetus does not, yet both have a similar total number of receptors or of their components (Table 3 ). Both qualitative and quantitative changes in glucagon receptor characteristics seem to participate in the augmented cAMP response. A maturational factor(s) distinct from receptor number or affinity also may participate; the factor(s) preventing coupling between the glucagon receptor and the adenylate cyclase complex at 56-58-d is not clear, but may be a component of the G/F regulatory protein as suggested by the progressive influence of 
Table 4. cAMP production by liver plasma membranes percentage increase above basal with different agents*

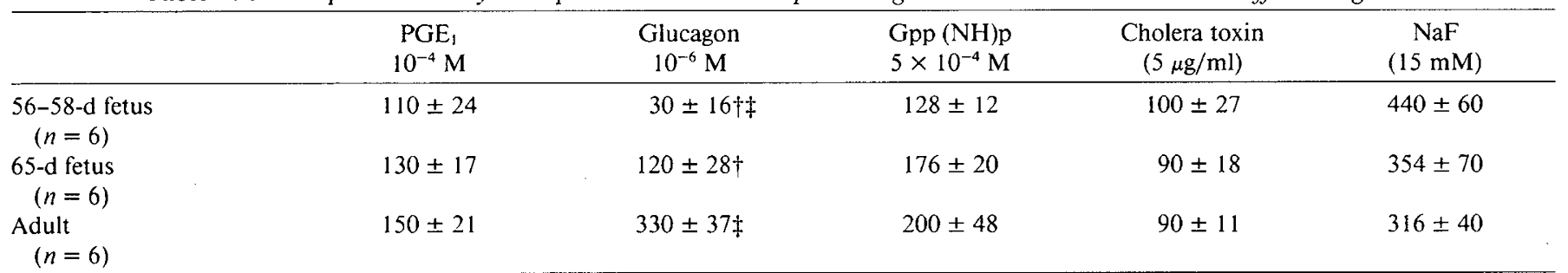

* Values are mean \pm SEM.

$\dagger P<0.05$ compared with adult.

$\ddagger P<0.05$ compared with 65 -d fetus.

GTP in altering the affinity of receptor for its ligand.

These results in maturing guinea pig differ from observations reported in developing rat $(42,46)$. At term and immediately after birth, rat liver membranes produce approximately $30 \%$ of adult cAMP response to maximum glucagon stimulation $\left(10^{-6}\right.$ M) despite only $10 \%$ of the amount of glucagon binding found in adult. The sensitivity of the adenylate cyclase complex at a post-receptor step appears to be greater in fetal/neonatal rat liver, and highlights differences between species. The validity and possible physiologic relevance of our in vitro observations is supported by in vivo and in vitro studies with newborn guinea pig $(16,36)$. Although glucagon failed to stimulate glycogenolysis in the initial $3 \mathrm{~h}$ of life, dibutyryl cAMP was effective, which suggests an inability of newborn guinea pig liver to generate appropriate amounts of cAMP in response to glucagon (16). Similarly, hepatic ketogenesis, a process under the influence of glucagon (20), is very low in newborn guinea pig and increases sharply after $24 \mathrm{~h}(36)$.

The glucagon receptors from adult liver are qualitatively different from their fetal counterparts, suggesting ongoing maturation. The affinity constant of high affinity sites is significantly lower in the adult whereas total receptor number and high affinity sites increase. From the binding data and the dose response curve, it can be shown that at a dose of glucagon at which $50 \%$ of high affinity sites are occupied, the cAMP response is not different from the 0 glucagon dose, both in adult and 65-d fetus. But the glucagon dose necessary for a $50 \%$ response in cAMP corresponds closely with the dose necessary for $50 \%$ receptor occupancy of the low affinity receptor population. It may be proposed that the low affinity glucagon receptors are functional; a change towards lower affinity for the receptors may represent a more mature population of receptor coupled to adenylate cyclase. As indicated, however, neither changes in number nor affinity can completely explain the progressive maturation of cAMP response to glucagon.

Changes in the insulin and glucagon receptor characteristics and cAMP responsiveness could not be attributed to differences in the membrane preparations. Membranes from the adult and the two fetal groups demonstrate a similar degree of purification in 5'-nucleotidase, insulin binding capacity, and insulin degradation. A significant disparity exists, however, in the levels of glucose-6-phosphatase. In adult membrane we found a 4-fold reduction in glucose-6-phosphatase concentration in the purified membrane as previously reported $(23,28)$. In fetal groups, the levels of glucose-6-phosphatase remain similar in both crude and purified membrane. This finding suggests a difference in the localization of glucose-6-phosphatase between adult and fetal liver because three other markers point to a comparable degree of purification in membranes from all ages studied. Furthermore, in spite of the identical purification of all markers used in the $65-\mathrm{d}$ and the 56-58-d group, glucagon binding as well as glucagon-stimulated cAMP production was significantly different at $65 \mathrm{~d}$.

In summary, the hepatic glucagon receptor and the adenylate cyclase complex appear to mature independently in the guinea pig liver and coupling between these two components remains incomplete until just before birth. The components of the adenylate cyclase complex, i.e., the $\mathrm{G} / \mathrm{F}$ regulatory protein and the catalytic unit, are present in functional form in the 56-58-d fetus, as evident from Gpp (NH)p, cholera toxin and NaF-stimulated cAMP production even though the response is not quantitatively at the adult level. Because components of the membrane adenylate cyclase complex respond well to various specific stimulatory agents, except to glucagon, and despite significant glucagon binding at $56-58 \mathrm{~d}$, we propose that in guinea pig, glucagon receptors, before term, are maintained in an uncoupled state. The coupling of glucagon receptors to post-receptor events at birth and further maturation of this process may have physiologic relevance in explaining the postnatal temporal pattern of glucagon-induced glycogenolysis and ketogenesis in this species (16, 36).

\section{REFERENCES AND NOTES}

1. Baginiski, E. S., Foa, P. P., and Zak, B.: Glucose-6-phosphatase In: H. U. Bergmeyer. Methods of Enzymatic Analysis. 2nd ed. Vol 2. p. 876 (Academic Press, Inc., New York, 1974).

2. Barr, H. P. and Hahn, P.: Development of rat liver adenyl cyclase. Can. J. Biochem. 49: 85 (1971).

3. Blazquez, E., Sugase, T., Blazquez, M., and Foa, P. P.: Neonatal changes in concentration of rat liver cyclic AMP and of serum glucose, free fatty acids, insulin, pancreatic, and total glucagon in man and in the rat. J. Lab. Clin. Med., 83: 957 (1974).

4. Blazquez, E., Rubalcava, B., Montesano, R., Orci, L., and Unger, R. H. Development of insulin and glucagon binding and the adenylate cyclase response in liver membranes of the prenatal, postnatal and adult rat: evidence of glucagon "resistance." Endocrinology, 98: 1014 (1976).

5. Butlen, D., Guillon, G., Cantau, B., and Jard, S.: Comparison of the developmental patterns of vasopressin. glucagon and alpha-adrenergic receptors from rat liver membranes. Mol. Cell. Endocrinol., 19: 275 (1980).

6. Cheng J. B. Goldfien, A., Cornett, L. E. and Roberts, J. M.: Identification of beta-adrenergic receptors using ${ }^{3} \mathrm{Hdihydroalprenolol}$ in fetal sheep heart: direct evidence of qualitative similarity to the receptors in adult sheep heart. Pediatr. Res., 15: 1083 (1981).

7. Clark, J. B., Vinicor, F., Carr, L., and Clark, C. M., Jr.: Adenyl cyclase responsiveness to guanyl nucleotides in the developing rat heart. Pediatr. Res., 14: 291 (1980).

8. deMeyts, P., and Roth. J.: Cooperativity in ligand binding: a new graphic analysis. Biochem. Biophys. Res. Commun., 66: 118 (1975).

9. Dixon. T. F., and Purdom, M.: Serum 5-nucleotidase. J. Clin. Pathol., 7: 341 (1954).

10. Enomoto, K., and Gill. D. M.: Cholera toxin activation of adenylate cyclase Roles of nucleoside triphosphates and a macromolecular factor in the ADP ribosylation of the GTP-dependent regulatory component. J. Biol. Chem. 255: $1252(1980)$.

11. Harden, T. K., Wolfe, B. B., Spron, J. R., Perkins, J. P., and Molinoff, P. B. Ontogeny of beta-adrenergic receptors in rat cerebral cortex. Brain Res., 125: 99 (1977).

12. Haymond, M. W. and Pagliara, A. S.: Endocrine and metabolic aspects of fuel homeostasis in the fetus and neonate. In: L. J. DeGroot, G. F. Cahill, Jr., L. Martini, D.H. Nelson, W.D. Odell, J.T. Potts, Jr., E. Steinberger, and A. I. Winegrad: Endocrinology. Vol. 3, pg. 1779 (Grune and Stratton, New York, 1979)

13. Jorgensen. K. H. and Larsen, U. D.: Purification of ${ }^{125}$ I-glucagon by anion exchange chromatography. Horm. Metab. Res., 4: 223 (1972).

14. Kaplan, S. A.: The insulin receptor. Pediatr. Res., 15: 1156 (1981).

15. Kaplan, S. L.. Grumbach, M. M., Shepard, T. H.: The ontogenesis of human fetal hormones. I. Growth hormone and insulin. J. Clin. Invest.. 5I: 3080 (1972). 
16. Kasai, Y. and Arinze, I. J.: Activation of glycogenolysis in neonatal liver. J. Biol. Chem., 256: 853 (1981)

17. Kelly, P. A., Posner, B. I., Tsushima. T., and Friesen, H. G.: Studies of insulin, growth hormone and prolactin binding: ontogenesis, effects of sex and pregnancy. Endocrinology, 95: 532 (1974).

18. Kohrman, A, F.: Patterns of development of adenyl cyclase activity and norepinephrine responsiveness in the rat. Pediatr. Res., 7: 575 (1973).

19. Lowry, O. H., Rosebrough, N. J., Farr, A. L., and Randall, R. J.: Protein measurement with the Folin phenol reagent. J. Biol. Chem., 193: 265 (1951).

20. McGarry. J. D.: New perspectives in the regulation of ketogenesis. Diabetes, 28: 517 (1979).

21. Neufeld. N. D., Kaplan, S. A., Lippe, B. M., and Scott, M.: Increased monocyte receptor binding of ${ }^{125} \mathrm{I}$-insulin in infants of gestational diabetic mothers. $J$. Clin. Endocrinol. Metab., 47: 590 (1978).

22. Neufeld, N. D., Scott, M., and Kaplan, S. A.: Ontogeny of mammalian insulin receptor. Studies of human and rat fetal liver plasma membranes. Dev. Biol., 78: $151(1980)$.

23. Neville. D. M.. Jr.: Isolation of an organ specific protein antigen from cellsurface membrane of rat liver. Biochim. Biophys. Acta, 154: 540 (1968).

24. Novak. E., Drummond, G. I., Skala. J., and Hahn, P.: Developmental changes in cyclic AMP, protein kinase, phosphorylase kinase, and phosphorylase in liver, heart and skeletal muscle of the rat. Arch. Biochem. Biophys., 150: $511(1972)$

25. Olson, F. C. and Massaro, E. J.: Developmental pattern of cAMP, adenyl cyclase. and cAMP phosphodiesterase in the palate, lung, and liver of the fetal mouse: alterations resulting from exposure to methylmercury at levels inhibiting palate closure. Teratology, 22: 155 (1980).

26. Osterthun, V., Haas, T., Peters, F., Petry, M., and Trautschold, I.: The assessment of glucagon binding in isolated intact neonatal and adult rat liver cells. Fresenius Z. Anal., 301: 191 (1980).

27. Pingoud, V. A.. Peters, F., Hass, T. D. U., and Trautschold, I.: A quantitative analysis of glucagon binding to isolated intact neonatal and adult rat hepatocytes on the basis of two different binding models. Biochim. Biophys. Acta, 714: 448 (1982).

28. Pohl, S. L.. Birnbaumer, L., and Rodbell, M.: The glucagon-sensitive adenyl cyclase system in plasma membranes of rat liver. J. Biol. Chem., 246: 1849 (1971).

29. Rall, L. B., Pictet. R. L., Williams, R. H., and Rutter, W. H.: Early differentiation of glucagon-producing celts in embryonic pancreas: a possible developmental role for glucagon. Proc. Natl. Acad. Sci. USA, 70: 3478 (1973).

30. Rodbell. M.: The role of hormone receptors and GTP-regulatory proteins in membrane transduction. Nature, 284: 17 (1980).

31. Rosenthal, H. E.: A graphic method for determination and presentation of binding parameters in a complex system. Anal. Biochem., 20:525 (1967).

32. Scatchard, G.: The attractions of proteins for small molecules and ion. Ann. N.Y. Acad. Sci., 51: 660 (1949).
33. Sinha, M. K.. Ganguli, S., and Sperling, M. A.: Disappearance of erythrocyte insulin receptors during maturation in sheep. Diabetes, 30:411 (1981)

34. Sodoyez, J. C.. Sodoyez-Goffaux, F., Fogg, M. M., Zimmerman, A. E., and Arquilla, E. R.: ${ }^{127}$ I-or carrier-free ${ }^{125}$ I monoiodoinsulin. J. Biol. Chem., 250: 4268 (1976).

35. Sperling. M. A.. Ganguli. S., Christensen, R.. and Voina, S.: Maternal diabetes does not alter postnatal development of the hepatic glucagon receptoradenylate cyclase system in the rat. Pediatr. Res., 17: 101 (1983).

36. Stanley, C. A.. Gonzales, E., and Baker, L.: Development of hepatic fatty acid oxidation and ketogenesis in the newborn guinea pig. Pediatr. Res., 17: 224 (1983).

37. Stave, U.: Enzyme development in the liver: In: U. Stave: Physiology of the Perinatal Period Vol 1 p. 559 (Appleton-Century-Crofts, New York, 1970)

38. Stciner, A. L., Kipnis, D. M., Utiger, R., and Parker, C.: Radioimmunoassay for the measurement of adenosine 3', 5'-cyclic phosphate. Proc. Natl. Acad. Sci. USA, 64: 367 (1969).

39. Steinke, J., and Driscoll, S. G.: The extractable insulin content of pancreas from fetuses and infants of diabetic and control mothers. Diabetes, 14: 573 (1965).

40. Thakur, A. K., Jaffe, M. L., and Rodbard, D.: Graphic analysis of ligandbinding systems: evaluation by Monte Carlo studies. Anal. Biochem., 107: $279(1980)$.

41. Thorsson, A. V. and Hintz, R. L.: Insulin receptors in the newborn. Increase in receptor affinity and number. N. Engl. J. Med., 297: 908 (1977)

42. Vinicor, F.. Higdon, G., Clark, J. F., and Clark, C. M., Jr.: Development of glucagon sensitivity in the neonatal rat liver. J. Clin. Invest., 58: 571 (1976).

43. Whitsett. J. A. and Johnson, C. L.: Guanine nucleotide regulation of adenylate cyclase in the guinea pig myocardium (developmental aspects) Pediatr. Res., 14: $463(1980)$.

44. Whitsett, J. A., Manton, M. A., Darovec-Beckerman, C., Adams, K. G., and Moore. J. J.: Beta-adrenergic receptors in the developing rabbit lung. Am. J. Physiol., 240: E351 (1981).

45. Whitsett, J. A., Darovec-Beckerman, C., Pollinger, J., and Moore, J. J.: Ontogeny of $\beta$-adrenergic receptors in the rat lung: effects of hypothyroidism. Pediatr. Res., 16: 381 (1982).

46. Yount, E. A.. Clark, J. F., and Clark, C. M., Jr.: Development of guanylylimidodiphosphate-dependent activation of adenylate cyclase by glucagon in the neonatal rat heart. Pediatr. Res., I0: 851 (1976).

47. Presented in part at the 62 nd Endocrine Society Meeting, Washington, D.C. 1980.

48. We gratefully acknowledge the secretarial assistance of Shirley Courtney.

49. Requests for reprints should be addressed to: Dr. S. Ganguli, Division of Endocrinology, Children's Hospital Medical Center, Cincinnati, OH 45229

50. This research was supported by grants from the USPHS HD 12613, HD 11725 , AM 05840, and by the Juvenile Diabetes Foundation.

\section{ERRATUM}

The authors regret their error in the footnotes of Table 11, which appeared in Pediatr. Res., 17: 1032 (1983). The two footnotes should read as follows:

$\dagger$ Number fatal in parentheses.

* Other includes encephalopathy (3), myocarditis (2), myositis (1), and idiopathic thrombocytopenic purpura (1). 